Original Research Article

\title{
Knowledge, attitude and practices towards medical research among resident doctors at a tertiary care hospital
}

\author{
Rajshree N. Mandhare, Venkatesh V. Khadke*, Saleem B. Tamboli
}

Department of Pharmacology,

Dr. Shankarrao Chavan

Government Medical College,

Nanded, Maharashtra, India

Received: 08 September 2019

Revised: 15 October 2019

Accepted: 16 October 2019

*Correspondence to:

Dr. Venkatesh V. Khadke,

Email: vyankatesh_khadke@ yahoo.com

Copyright: (C) the author(s), publisher and licensee Medip Academy. This is an openaccess article distributed under the terms of the Creative Commons Attribution NonCommercial License, which permits unrestricted noncommercial use, distribution, and reproduction in any medium, provided the original work is properly cited.

\begin{abstract}
Background: Research is a systematic process utilizing the scientific method for generating new knowledge that can be used to solve a problem or improving the existing status of a system. Human being is living a life of ease due to research in medical field. But it is important to know that whether those who are closest to society like resident doctors are involved in research process or not. Thus, the present study is planned to assess the knowledge, attitude and practice of resident doctors in a tertiary care hospital.

Methods: This was the questionnaire-based study conducted among the resident doctors. Sample size calculated was 110 by open Epi software. A selfstructured questionnaire was validated and distributed. Then we collected the data which was analysed using statistical analysis with MS excel and SPSS software version 21 .

Results: The $62 \%$ response rate was achieved. More than $50 \%$ of the resident doctors have the knowledge of $\mathrm{p}$ value and protocol writing. $63 \%$ students are strongly agreed that research in medical field is important while only $19 \%$ students are strongly disagreed that research increases burden over students $17 \%$ of the students have presented research paper. More than $75 \%$ student told that there are many barriers conducting research.

Conclusions: This study demonstrates that more than $50 \%$ respondents have the basic knowledge about the medical research and they have the positive attitude too. But there is lack of the practices regarding research. Thus, there should be some efforts to improve practices of medical research among resident doctors.
\end{abstract}

Keywords: Biomedical research, Ethics, Patient care

\section{INTRODUCTION}

Research is a key ingredient in shaping up the world that man lives in and the new experiences they see and encounter in their surroundings. ${ }^{1}$ As a human being, we have progressed from ancient life to today's new lifestyle due to unstoppable efforts of man in the research. Of course, medical field is not an exception to it. Here research benefits in the form of new advancements in treatments as well as various diagnostic methods. Over past few decades is transforming the practice of medicine from 'experience based' to 'evidence based'. Evidence based medicine is the process of systematically finding, evaluating and using contemporary research findings as the basis of clinical decisions. ${ }^{2}$ All well designed research studies have the potential to contribute for the evidencebased medicine, even though they do not provide the definitive results.

Also, while practicing, today's doctor should be skilled in techniques in literature search to know the appropriateness of the various researches which have been published. Thus, every doctor should strive to contribute to the generation of evidence by conducting research. 
Charles Best was a medical student when he with his supervisor, Frederick Banting, discovered insulin. Paul Langerhans a medical student proved that insulin arises from pancreatic islets of Langerhans. Alan Hodgkin won the Nobel Prize in 1972 in biomedical research work on nerve transmission that he began as an undergraduate, he was formerly professor of biophysics at the University of Cambridge.

It is essential to create the students' interest towards research, so that the good quality of research can be conducted to improve the medical health care system existing in the nation as well as in the world. ${ }^{4}$ This is necessary as the modern medical science is growing leaps and bounds and the update for any medical doctor is necessary for overall societal betterment. Also, it provides an academic challenge and a self-learning experience to the students. The Indian Council of Medical Research initiated the short term studentship program in 1979 in order to promote interest and aptitude for research among medical undergraduates. ${ }^{5}$ The main objective of this program was to provide an opportunity to undergraduate medical students to familiarize themselves with the research methodology and techniques.

Postgraduate (PG) thesis is aimed at contributing to the development of the spirit of enquiry, besides exposing the PG student to the technique of research, critical analysis, acquaintance with the latest advances in the medical science and the manner of identifying and consulting available literature. Many universities in India have made PG dissertation compulsory because PG students in medicine and allied sciences should be proficient not only in their respective subjects but also in research.

In order to encourage research orientation in PG students, now it is mandatory to not only attend national or state conference but also give an oral or poster presentation and send article for publication. ${ }^{6}$ Scientific training about research is also given to resident doctors in research methodology workshops arranged by the university.

Knowledge on principles of research is important among resident doctors, so that they can conduct well planned and high-quality research which directly or indirectly contributes for advancement of medical health care system. ${ }^{7}$ But over 25 years there has been serious decrease in medical graduates choosing clinical scientist carrier. ${ }^{8}$ Therefore, it is important to know that, resident doctors who are directly involved in patient care are interested in research process or not.

Thus, the present study was planned to assess the knowledge, attitude and practice towards medical research in resident doctors at a tertiary care hospital.

\section{METHODS}

This was the questionnaire based cross sectional study conducted among the resident doctors of the Dr. Shankarrao Chavan Government Medical College, Nanded, during September-October 2018.

After reviewing the literature in context of the research interests in students, a questionnaire was designed to assess the knowledge, attitude and practices towards research among the resident doctors. It consisted of total 33 questions. Out of which thirteen questions were multiple choice questions for the assessment of knowledge. The questions and the response is given in table 2. Next section of questionnaire was of ten attitude related questionnaires (Table 1).

Table 1: Attitude related questions.

\begin{tabular}{|l|l|}
\hline Question 1 & Role of research in medical field is important \\
\hline Question 2 & You are interested in doing research in future? \\
\hline Question 3 & Training for research methodology should be compulsory for PG students \\
\hline Question 4 & Research enhances better patient care \\
\hline Question 5 & Research conduction reinforce teamwork spirit \\
\hline Question 6 & $\begin{array}{l}\text { You require seminars or workshops or continuing medical education periodically } \\
\text { to update the knowledge on research principles }\end{array}$ \\
\hline Question 7 & You are interested in reviewing the articles in journals as reviewer. \\
\hline Question 8 & Conducting research increases burden over medical students. \\
\hline Question 9 & PG medical students should not be involved in medical research \\
\hline Question 10 & You are participating in research as it is made compulsory by the university \\
\hline
\end{tabular}

This section had Likert scale. Final section was for determining the practice regarding research. It consisted of ten questionnaires to which we gave options as yes or no.

An approval from institutional ethics committee of was obtained. The knowledge, attitude and practices study questionnaire was validated by panel of professionals having experience in research. The questionnaire was revised as per the suggestions of panel members. The revised questionnaire was revalidated by the panel.

Following validation, we conducted one pilot study among ten resident doctors who were not the part of the actual study. Further we calculated the Cronbach's alpha coefficient which was 0.83 by using SPSS software 
version 21. This showed the reliability of our attitude related ten questions.

The sample size of 110 participants was calculated by using Open Epi software, version 3 by taking hypothesized $\%$ frequency of outcome factor in the population (p) as $50 \%+/-5$ confidence limits as $\%$ of 100 (absolute $+/-\%$ ) (d): $5 \%$. After obtaining the informed consent we distributed 110 questionnaires to the resident doctors of every department personally. The study participants included the resident doctors from all the departments. We excluded the senior residents, house officers, bonded lecturers and interns. After obtaining the informed consent, we instructed them about the questionnaire and regarding marking the answers to the questions. They were provided with sufficient time to answer the questionnaire. The questionnaires were collected and data obtained was analysed. We entered all the collected data in Microsoft Excel sheet and analysed by SPSS software and Microsoft excel. For references and citations, Vancouver style has been used.

\section{RESULTS}

Out of 110 doctors to whom we distributed questionnaire; the response rate was $62 \%$. Among those, $7 \%$ were final year, $32 \%$ were of second year, $60 \%$ were first year resident doctors.

Table 2 shows the knowledge questionnaires with options and percentage of students having correct response.
Figure 1 only shows the response regarding attitude related questions.

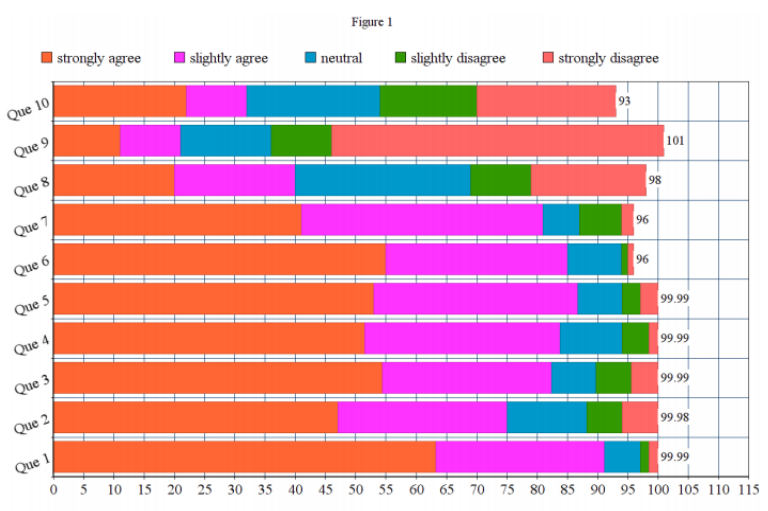

Figure 1: Results regarding attitude related questions.

Our results show that more than $50 \%$ students are strongly agree that role of research is important, training should be compulsory, research enhances better patient care and research conduction reinforce teamwork spirit. $55 \%$ students are strongly agreed that workshops, seminars, continuing medical education are important and $55 \%$ students are strongly disagree that medical students should not be involved in medical research. But $29 \%$ students remain neutral about the burden over medical students and $22 \%$ students are strongly agreed that they are participating in research because of compulsion by the university.

Table 2: Knowledge questionnaires with options and percentage of students having correct response.

\begin{tabular}{|c|c|c|c|c|c|}
\hline Questions & Option A & Option B & Option C & Option D & $\begin{array}{l}\text { Correct } \\
\text { response } \\
(\%)\end{array}$ \\
\hline $\begin{array}{l}\text { 1) Why should we do } \\
\text { research? }\end{array}$ & $\begin{array}{l}\text { To understand } \\
\text { concept in } \\
\text { specialized area }\end{array}$ & $\begin{array}{l}\text { To generate multitude } \\
\text { of ideas }\end{array}$ & $\begin{array}{l}\text { To provide } \\
\text { improved } \\
\text { insights }\end{array}$ & All of the above & 88 \\
\hline $\begin{array}{l}\text { 2) From whom the } \\
\text { protocol should be } \\
\text { approved before } \\
\text { research initiation at } \\
\text { institutional level? }\end{array}$ & $\begin{array}{l}\text { Drug Controller } \\
\text { General of India }\end{array}$ & $\begin{array}{l}\text { Institutional ethics } \\
\text { committee }\end{array}$ & $\begin{array}{l}\text { Clinical Trials } \\
\text { Registry- India }\end{array}$ & $\begin{array}{l}\text { Central Drugs } \\
\text { Standard } \\
\text { Control } \\
\text { Organization }\end{array}$ & 76 \\
\hline $\begin{array}{l}\text { 3) What is the long } \\
\text { form of IEC? }\end{array}$ & $\begin{array}{l}\text { Indian ethical } \\
\text { committee }\end{array}$ & $\begin{array}{l}\text { Institutional ethics } \\
\text { committee }\end{array}$ & $\begin{array}{l}\text { Information } \\
\text { education } \\
\text { communication }\end{array}$ & $\begin{array}{l}\text { None of the } \\
\text { above }\end{array}$ & 71 \\
\hline $\begin{array}{l}\text { 4) Which are the } \\
\text { contents of research } \\
\text { protocol? }\end{array}$ & $\begin{array}{l}\text { Title and } \\
\text { introduction }\end{array}$ & Methodology & $\begin{array}{l}\text { Aim and } \\
\text { objectives of the } \\
\text { study }\end{array}$ & All of the above & 97 \\
\hline $\begin{array}{l}\text { 5) How would you } \\
\text { define research } \\
\text { hypothesis? }\end{array}$ & $\begin{array}{l}\text { A proposed idea } \\
\text { or thought }\end{array}$ & $\begin{array}{l}\text { An answer or } \\
\text { solution to a question } \\
\text { which has a capacity } \\
\text { of verification }\end{array}$ & $\begin{array}{l}\text { An answer or } \\
\text { solution to a } \\
\text { question }\end{array}$ & $\begin{array}{l}\text { None of the } \\
\text { above }\end{array}$ & 56 \\
\hline $\begin{array}{l}\text { 6) The justification or } \\
\text { rationale of the study } \\
\text { should not include }\end{array}$ & $\begin{array}{l}\text { Reasons for } \\
\text { conducting } \\
\text { research }\end{array}$ & $\begin{array}{l}\text { Introduction for } \\
\text { research }\end{array}$ & $\begin{array}{l}\text { About the most } \\
\text { relevant studies } \\
\text { published on the } \\
\text { subject }\end{array}$ & $\begin{array}{l}\text { Study design, } \\
\text { aim and } \\
\text { objectives }\end{array}$ & 29 \\
\hline
\end{tabular}




\begin{tabular}{|c|c|c|c|c|c|}
\hline Questions & Option A & Option B & Option C & Option D & $\begin{array}{l}\text { Correct } \\
\text { response } \\
(\%)\end{array}$ \\
\hline $\begin{array}{l}\text { 7) Test group and } \\
\text { control group }\end{array}$ & $\begin{array}{l}\text { should not be } \\
\text { from the same } \\
\text { age group }\end{array}$ & $\begin{array}{l}\text { should have different } \\
\text { diseases }\end{array}$ & $\begin{array}{l}\text { should resemble } \\
\text { each other }\end{array}$ & All of the above & 63 \\
\hline $\begin{array}{l}\text { 8) In Vancouver style } \\
\text { of reference, which of } \\
\text { the following is } \\
\text { incorrect }\end{array}$ & $\begin{array}{l}\text { Use of "and" in } \\
\text { between } \\
\text { authors' name }\end{array}$ & $\begin{array}{l}\text { Add et al after } 3 \\
\text { authors' name if } \\
\text { more than } 6 \text { authors }\end{array}$ & $\begin{array}{l}\text { Abbreviate page } \\
\text { number as "p." }\end{array}$ & All are correct & 29 \\
\hline $\begin{array}{l}\text { 9) Good clinical } \\
\text { practice guidelines } \\
\text { are for }\end{array}$ & $\begin{array}{l}\text { Good Patient } \\
\text { Care practices }\end{array}$ & $\begin{array}{l}\text { Good Clinical } \\
\text { Practice for trials on } \\
\text { pharmaceutical } \\
\text { product }\end{array}$ & $\begin{array}{l}\text { Good clinical } \\
\text { services in } \\
\text { government } \\
\text { hospitals }\end{array}$ & $\begin{array}{l}\text { None of the } \\
\text { above }\end{array}$ & 57 \\
\hline $\begin{array}{l}\text { 10) Which of the } \\
\text { following is the Drug } \\
\text { regulatory authority } \\
\text { in India? }\end{array}$ & $\begin{array}{l}\text { Drug Controller } \\
\text { General of India }\end{array}$ & $\begin{array}{l}\text { Central Drugs } \\
\text { Standard Control } \\
\text { Organization }\end{array}$ & $\begin{array}{l}\text { Indian Council } \\
\text { of Medical } \\
\text { Research }\end{array}$ & $\begin{array}{l}\text { Clinical Trials } \\
\text { Registry- India }\end{array}$ & 48 \\
\hline $\begin{array}{l}\text { 11) What is the } \\
\text { significant } p \text { value for } \\
\text { most of the studies? }\end{array}$ & $<1$ & $>0.01$ & $<0.05$ & $\begin{array}{l}\text { None of the } \\
\text { above }\end{array}$ & 58 \\
\hline $\begin{array}{l}\text { 12) Informed consent } \\
\text { form should include } \\
\text { all except }\end{array}$ & $\begin{array}{l}\text { Name of the } \\
\text { research worker }\end{array}$ & $\begin{array}{l}\text { Signature of the } \\
\text { participant }\end{array}$ & $\begin{array}{l}\text { Details of the } \\
\text { research work } \\
\text { and justification }\end{array}$ & $\begin{array}{l}\text { Signature of the } \\
\text { witness }\end{array}$ & 22 \\
\hline $\begin{array}{l}\text { 13) All of the } \\
\text { following statements } \\
\text { are correct except }\end{array}$ & $\begin{array}{l}\text { The control } \\
\text { group should be } \\
\text { given placebo }\end{array}$ & $\begin{array}{l}\text { Placebo must look } \\
\text { like test drug }\end{array}$ & $\begin{array}{l}\text { Giving placebo } \\
\text { to participant is } \\
\text { always ethical }\end{array}$ & All are correct & 48 \\
\hline
\end{tabular}

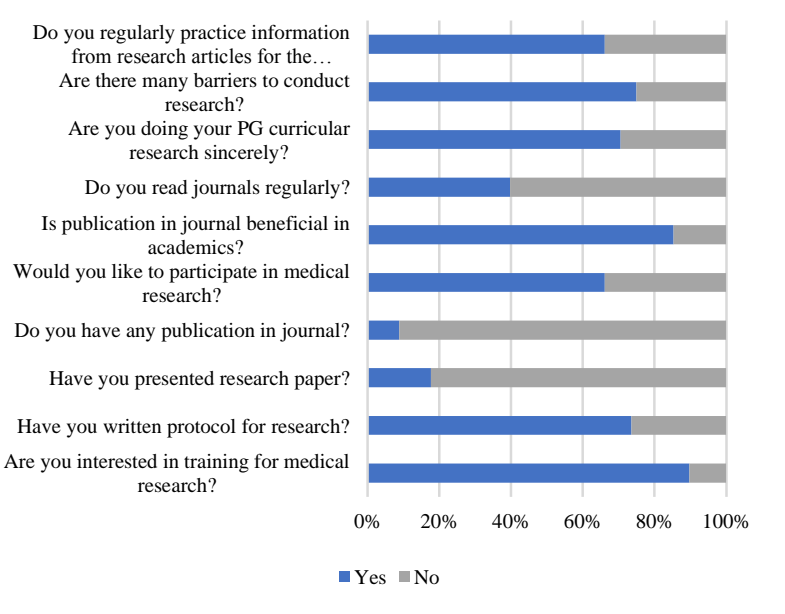

Figure 2: Practice related questions and their response.

Figure 2 shows that 45 students out of 68 regularly refer information from published research. More than $75 \%$ student accepted that there are many barriers conducting research. Less than $30 \%$ students are not doing PG curricular research sincerely. $60 \%$ students read journals regularly. $85 \%$ students know about the academic benefits of publication in journal. $66 \%$ students want to participate in the medical research. Only $8 \%$ students have the publication in journal. Less than $20 \%$ of the students have presented research paper. $89 \%$ students are interested in training for medical research. $73 \%$ students have written protocol for research.

\section{DISCUSSION}

A PG student at the end of his post-graduation, should be capable of planning and carrying out an independent research project. It helps them to develop the necessary skills required to do the research. Such skills will also help them to critically analyse the medical literature. Unless one is familiar with the basics of research they cannot assess the relative merits and demerits of new drugs and new treatment.

Our study focuses on the knowledge, attitude and practices of the resident doctors towards research. Understanding the perceptions and attitudes of students towards research can lead to improvement of research practices among future physicians. Our study confirms the fact that more than $50 \%$ of students have adequate knowledge about research as research methodology workshop is mandatory by Health University for all resident doctors. However, the practices regarding the research are not adequate. But there is positive attitude among resident doctors.

Our study is comparable to the study conducted by Madhavrao at Kulsekharam at Tamil Nadu. They 
observed that more than $50 \%$ of study participants were able to answer the correct response for questions on knowledge about the principles of research. However, the practice seems to be not satisfactory. It was noticed that only $7.69 \%$ of study participants had experience in sending the manuscript for publication in peer reviewed journals. ${ }^{9}$ But a survey at Andhra Pradesh reported poor level of knowledge as well as poor participation of PG students. ${ }^{10}$

In our survey, more than $50 \%$ students responded that there are many barriers in conducting a research. Also $60 \%$ students have interest in training in biomedical research. Similarly, a study conducted in Oman in 2015 shows the significant difference $(\mathrm{p}=0.001)$ regarding barrier of research. ${ }^{11}$

Our study findings were similar to the study carried by Pawar et al at Department of Pharmacology, Mumbai to evaluate the awareness about medical research among resident doctors at tertiary care hospital. ${ }^{12}$ The above study concluded that $58 \%$ of residents had the knowledge about the research hypothesis concept, $76 \%$ agreed to have adequate training in research, $98 \%$ were aware of obtaining the consent in case of human related research, $4 \%$ published the research work in various journals, $50 \%$ were engaged in carrying out research other than their dissertation work, $88 \%$ opined to carry out research in their future professional period and $28 \%$ had presentations at various conferences. Our study results show that $56 \%$ of residents have the knowledge about the research hypothesis, $22 \%$ residents know about the informed consent form, $8 \%$ published the research work in various journals. Our study also highlighted various points as only $9 \%$ students read the journals regularly. But $66 \%$ students know that publication in journal is beneficial further in academics.

A cross-sectional study carried out in King Abdelaziz University, Jeddah revealed that knowledge about research was generally low. Study participants who received research training and conducted researches had significantly higher knowledge score compared to others. Positive research attitude was present. Regarding practice, $38.1 \%$ of medical students and interns participated in researches and $5.8 \%$ published a scientific paper. Our study also shows positive research attitude as greater than $50 \%$ students strongly agreed that role of research in medical field is important and more than $45 \%$ students are interested in doing research in future. ${ }^{13}$ Also $70 \%$ of all students surveyed were interested in participating in research during medical school in a study conducted in one medical school at New Zealand. ${ }^{14}$

A cross sectional questionnaire-based study was carried out in post graduate students of Sri Siddhartha Medical College, Tumkur concluded that $78 \%$ students agreed that qualities of services provided to patients will be increased with continued research work. ${ }^{15}$ In our study $52 \%$ students strongly agreed and $30 \%$ students slightly agreed that research enhances better patient care. But small sample size is the major limitation of our study.

\section{CONCLUSION}

Biomedical research creates scientific approach towards health problems of society. Even though the PG students are exposed to the field of research for the first time, $50 \%$ of them have basic knowledge of medical research. Our study highlighted the interest and positive attitude of PG students about research related activities. There are barriers to conduct research related work. Exposure of undergraduate students should be encouraged to participate in research conducted by health universities and Indian Council of Medical Research. Also, due importance should be given to PG dissertation work.

\section{ACKNOWLEDGEMENTS}

We are thankful to all the participants and panel members. We acknowledge all the authors and journals whose articles are referred by us.

\section{Funding: No funding sources}

Conflict of interest: None declared

Ethical approval: The study was approved by the Institutional Ethics Committee

\section{REFERENCES}

1. Oguan FE, Bernal MM, Pinca CMD. Attitude and anxiety towards research, its influence on the students' achievement in the course. Asian J Manag Sci Educ. 2014;3(4):165-72.

2. Tripathi KD. Aspects of pharmacotherapy, clinical pharmacology and drug development. Essentials of Medical Pharmacology. 8th ed. India: Jaypee Brothers Publisher; 2019: 83.

3. Metcalfe D. Involving medical students in research. J R Soc Med. 2008;101(3):102-3.

4. Guidelines for good clinical practice (GCP) for trials on pharmaceutical products. World Health Organization WHO Technical Report Series; 1995: Annex 3: 850 .

5. Jadhav GS, Dubhashi S, Buch A, Chandanwale S. Assessment of the impact of short term studentship program on attitude of undergraduate medical students toward future research. Med J D.Y. Patil Vidyapeeth. 2014;7(6):696-700.

6. PG Academic Notification No. 20/2010. 2011; 2539195.

7. Gore AD, Kadam YR, Chavan P V, Dhumale GB. Application of biostatistics in research by teaching faculty and final-year postgraduate students in colleges of modern medicine: a cross-sectional study. Int J Appl Basic Med Res. 2012;2(1):11-6.

8. Deodurg PM, Bagewadi HG, Patil BV, Dass AP. Knowledge, attitude and perceptions of $3 \mathrm{rd}$ term medical students towards clinical trials in a medical 
college in southern India. Indian $\mathbf{J}$ Pharmacy Pharmacol. 2017;4:125-9.

9. Madhavrao C, Bai MK, Menon RN, Babu SK, Asir PA. Knowledge attitude and practices towards principles of research among medical postgraduates in a teaching tertiary care centre. Int J Cur Res Rev. 2016;8(2):4-9.

10. Reddy M. Attitudes and practices of students towards the National Premarital Screening Program of Saudi Arabia. Indian J Basic Appl Med Res. 2016;5(3):5139.

11. Jahan F, Maqbali A Al. Attitude and barrier towards research amongst health care professionals working in primary care service of Oman. J Heal Educ Res Dev. 2015;03(03):2-6.

12. Pawar D, Gawde S, Marathe P. Awareness about medical research among resident doctors in a tertiary care hospital: a cross-sectional survey. Perspect Clin Res. 2012;3(2):57.

13. Ibrahim RNK, Fetyani DM, Bashwari J. Assessment of the research-oriented knowledge, attitude and practice of medical students and interns of the King Abdulaziz University, Jeddah and the adoption of a research-intervention educational program. Rawal Med J. 2013;38(4):432-9.

14. Park SJK, McGhee CNJ, Sherwin T. Medical students' attitudes towards research and a career in research: An Auckland, New Zealand study. N Z Med J. 2010;123(1323):34-42.

15. Hk S, Deepali A, Bs K, Sh M. A cross sectional study on attitude, knowledge and barriers towards research among medical post graduate students. 2017;4(1):422-6.

Cite this article as: Mandhare RN, Khadke VV, Tamboli SB. Knowledge, attitude and practices towards medical research among resident doctors at a tertiary care hospital. Int J Basic Clin Pharmacol 2019;8:2517-22. 